\title{
VII. IN MEMORIAM
}

\section{Jerzy Reder (1927-2011)}

W dniu 7 maja 2011 r. w Lublinie zmarł dr hab. Jerzy Reder, docent w Uniwersytecie Marii Curie-Skłodowskiej, a po przejściu na emeryturę prof. nadzw. w Katolickim Uniwersytecie Lubelskim Jana Pawła II i następnie w Wyższej Szkole Ekonomii i Innowacji w Lublinie.

Jerzy Reder urodził się 18 lutego 1927 r. na Lubelszczyźnie, w Majdanie Ruszowskim. W latach II wojny światowej (1943-1944) był czynnym żołnierzem w szeregach Armii Krajowej, równolegle ucząc się na tajnych kompletach. Świadectwo dojrzałości otrzymał w roku 1946, a następnie podjął studia prawnicze na KUL-u, które ukończył w $1950 \mathrm{r}$. W tymże roku związał się z UMCS i w uczelni tej przepracował 42 lata: najpierw w Katedrze Historii Państwa i Prawa Polskiego, od 1963 r. w Katedrze Powszechnej Historii Państwa i Prawa, a po przekształceniach organizacyjnych Wydziału Prawa i Administracji w Katedrze Historii Państwa i Prawa. Doktoryzował się w 1972 r. na podstawie pracy pt. Podzialy polityczne i administracyjne Malopolski w czasach rozbiorów i niewoli, pod kierunkiem prof. Józefa Mazurkiewicza (recenzentami byli profesorowie Jan Wąsicki i Witold Sawicki). W 1988 r. Jerzy Reder habilitował się w UMCS na podstawie rozprawy (złożonej ze zwartego cyklu opracowań) zatytułowanej Dzieje podziatów administracyjnych Lubelszczyzny $i$ ziem sasiednich. Ocenę jego dorobku, ze skutkiem pomyślnym, przedstawili profesorowie: Władysław Sobociński, Wiesław Śladkowski, Jan Wąsicki, Edmund Klein. Na uzyskanym wówczas stanowisku docenta przepracował jeszcze w UMCS cztery lata, by w 1992 r. przejść na emeryturę.

Jerzy Reder pozostawił po sobie interesujący i znaczący dorobek naukowy z historii ustroju i administracji tak w dawnej Polsce, jak i w latach zaborów. Nie był on ilościowo zbyt imponujący (w sumie sięgający 50 różnorodnych opracowań), ale poświęcony zagadnieniom ważnym i mało znanym, szczególnie w zakresie dziejów administracji polskiej. Głównym przedmiotem Jego zainteresowań badawczych pozostawały dzieje dawnych podziałów politycznych i administracyjnych państwa. Zajmował się także historią ustroju miast w połączeniu $\mathrm{z}$ instytucjami sądowymi czy też nauczaniem prawa w Polsce szlacheckiej. Wszystkie Jego prace odznaczały się doskonałą znajomością 
źródeł archiwalnych, nie tylko prawnych, ale i kartograficznych, szerokim wykorzystaniem literatury. Podejmował tematykę zazwyczaj w ujęciu regionalnym, a następnie przechodził do ustaleń o bardziej generalnym charakterze, przedstawiając wnioski i tezy mające ogólne znaczenie oraz dające się wykorzystać do ujęć syntetycznych czy systemowych.

Będąc uczniem Józefa Mazurkiewicza w 1954 r. udanie zadebiutował publikując w „Czasopiśmie Prawno-Historycznym” rozprawę zatytułowaną Poslowie miasta Lublina na sejmy dawnej Rzeczypospolitej (t. VI, z. 2). W tymże roku na łamach „Annales UMCS” (sec. G, vol. 1) ukazała się obszerna, przeszło 100-stronicowa praca pt. Miasta prywatne powiatu lubelskiego a ich dziedzice $w X I X w$. będąca efektem działań zespołu naukowego pod kierunkiem Mazurkiewicza, powołanego do prekursorskich badań nad problematyką miast prywatnych. Jerzy Reder był jej współautorem (obok wspomnianego J. Mazurkiewicza i J. Markiewicza). Obydwie rozprawy do dziś pozostaja w obiegu naukowym. W artykule Posłowie miasta Lublina, Autor przekonywająco udowodnił aktywną obecność przedstawicieli miasta na sejmach Rzeczypospolitej od XVI do XVIII stulecia z ogólną tezą potwierdzającą udział przedstawicieli głównych miast Polski w szlacheckim parlamencie. Lubelską tematyką miejską zajmował się Jerzy Reder jeszcze parokrotnie. Opublikował m.in. ciekawy szkic pt. Zamość jako stolica regionu (w: Czterysta lat Zamościa, Ossolineum 1983), artykuł Wzrost znaczenia Lublina i jego położenie przesłanka umiejscowienia Trybunatu Koronnego (w: 400-lecie utworzenia Trybunatu Koronnego w Lublinie, Lublin 1982), w Dziejach Lubelszczyzny (t. VI, Warszawa 1989) pisał O wpływie szkól katolickich i różnowierczych na znajomość prawa i zagadnień politycznych $w$ Lubelskiem $w$ wiekach XVI-XVII. W 1997 r. był współautorem (z Tomaszem Opasem) książki Bełżyce. Studia i szkice z dziejów miasta, pisząc o ustroju tego podlubelskiego miasta w czasach stanisławowskich i latach zaborów.

Od lat 60. ubiegłego wieku Jerzy Reder skoncentrował się zarówno na badaniach podziałów politycznoadministracyjnych w przeszłości państwa polskiego i ich wpływie na organizację aparatu władzy, jak i efektach społecznych. Można powiedzieć, że wkroczył w obszar badawczy historii administracji, ale i geografii politycznej, widząc w kształtowaniu podziałów terytorialnych uwarunkowania historyczne, dalekosiężne skutki doraźnej polityki oraz ich wpływ na losy ludności miejscowej, ,,przenoszonej” zazwyczaj odgórnymi decyzjami na kolejne obszary administracyjne. Szczególnie uwidaczniało się to w epoce zaborów. Ujmował więc kwestie podziałów administracyjnoterytorialnych $z$ punktu widzenia potrzeb badawczych historii ustroju i administracji, ale doskonała znajomość problematyki geograficzno-kartograficznej i konieczna w tym przypadku szczegółowość oraz precyzyjność wywodów przyniosły $\mathrm{w}$ efekcie wysoki poziom prac i ich przydatność dla różnych dziedzin nauki oraz praktyki na szczeblu i lokalnym, i centralnym. Przy tak zmiennych losach 
i przesunięciach terytorialnych państwa polskiego rozprawy Jerzego Redera uświadamiają nam historyczną i terytorialną trwałość pewnych regionów (np. Wielkopolska), rozpad niektórych pojęć (np. Małopolska utożsamiana niesłusznie tylko z Galicja) czy też degradację innych (jak Sandomierskie). Pokazują rozmaitość rozwiązań dokonywanych przez zaborców, zazwyczaj z racji politycznych, ale $\mathrm{i}$ ich elementy nowoczesne (Prusy, Księstwo Warszawskie) i także już trwałe, bo skutkujące do dzisiaj w funkcjonujących jednostkach administracyjnych różnych szczebli, nazwach województw czy też nadaniu określonym miastom charakteru ich siedzib stołecznych.

$\mathrm{Na}$ kanwie badań nad pracą doktorska, która nie została opublikowana, pisał Reder o podziałach administracyjnych Małopolski (w rozumieniu dawnej prowincji w Rzeczypospolitej szlacheckiej) zarówno w latach rozbiorów („Palestra” 1974, nr 7), Księstwa Warszawskiego („Annales UMCS”, sec. G, vol. XX, 1973), ściśle o Małopolsce Południowej w okresie 1815-1867 (Prawnicze, administracyjne i ekonomiczne studia wyższe w Rzeszowie 1959-1974, Rzeszów 1975). Przedstawił również Zarys dziejów podziałów terytorialnych Pomorza Nadwiślańskiego (w: Pomorze Nadwiślańskie, Toruń 1992) i Delimitacje granic po III rozbiorze Polski (w: Miscellanea Historico-Iuridica Bialostocensia pod red. P. Fiedorczyka i A. Nowakowskiego, Białystok 1995). Szczegółowiej też zajął się dwoma historycznymi regionami Polski, publikując w CPH najpierw właśnie Sandomierskie - dzieje degradacji regionu (t. LIII, 2001, z. 2), a następnie Podlasie. Z dziejów ustroju terytorialnego i nazewnictwa (t. LVI, 2004, z. 1). W 1993 r. na łamach "Annales UMCS" (sec. G, vol. XL, 1993) ukazało się Jego interesujące studium zatytułowane Ustrojowo-prawna geneza stolic polskich województw w ujęciu historycznym. Przedstawił w nim precyzyjną specyfikację polskich miast wojewódzkich (wówczas jeszcze 49), opartą na proponowanych kryteriach: (a) politycznogeograficznych, (b) historyczno-tradycyjnych, (c) wynikających $\mathrm{z}$ dawnych stosunków własnościowych.

$\mathrm{Na}$ oddzielne podkreślenie zasługuje napisana wspólnie z Władysławem Ćwikiem książka Lubelszczyzna. Dzieje rozwoju terytorialnego, podziałów administracyjnych i ustroju władz (Lublin 1977, s. 208). Opracowanie to, obok oczywistych walorów regionalnych, ma istotne znaczenie dla badań nad historia polskiej administracji, ciagle bowiem pozostaje jednym z nielicznych ujęć o charakterze historycznoprawnym.

Jerzy Reder w UMCS wykładał polską i powszechną historię prawa. Jego seminarium ukończyło przeszło 80 absolwentów studiów prawniczych. Piastował też różnorodne funkcje organizacyjne w tymże Uniwersytecie.

W Katolickim Uniwersytecie Lubelskim został zatrudniony w 2000 r. na stanowisku profesora nadzwyczajnego i mianowany w Wydziale Zamiejscowym w Tomaszowie Lubelskim kierownikiem Katedry Historii Ustroju Polski na tle Powszechnym. W tym charakterze pracował do 2007 r., mając wykła- 
dy i seminarium $z$ historii ustroju Polski na tle powszechnym. Wypromował 20 magistrów prawa. Po zakończeniu pracy na KUL-u ostatnim miejscem zatrudnienia była lubelska Wyższa Szkoła Ekonomii i Innowacji, w której na studiach administracyjnych prowadził zajęcia z historii administracji.

Był porucznikiem Wojska Polskiego w stanie spoczynku. Odznaczony został między innymi Krzyżem Kawalerskim Orderu Odrodzenia Polski, Medalem Komisji Edukacji Narodowej, Krzyżem Armii Krajowej, Krzyżem Partyzanckim, brązowym medalem Zasłużony na Polu Chwały, medalem Za Zasługi dla UMCS oraz złotym medalem Za Zasługi dla Miasta Lublina.

W pamięci naszej, przyjaciół i współpracowników z Katedry Historii Państwa i Prawa UMCS, Jerzy Reder pozostanie jako dobry i uczynny człowiek, zawsze życzliwy, służący radą w sprawach naukowych czy dydaktycznych. Był postacią łączącą w sobie dużą wiedzę, kulturę osobistą z zamiłowaniami myśliwskimi i podróżniczymi oraz ceniąca uroki życia towarzyskiego.

WOJCIECH WITKOWSKI (Lublin) 